\title{
Antioxidant Status and Nitric Oxide in the Malnutrition Syndrome Kwashiorkor
}

\author{
ANKE FECHNER, CATHARINA C. BÖHME, STEPHAN GROMER, MATTHIAS FUNK, \\ R. HEINER SCHIRMER, AND KATJA BECKER \\ Interdisciplinary Research Center, Giessen University, DE-35392 Giessen, Germany [A.F., C.C.B., K.B.]; \\ Center of Biochemistry, Heidelberg University, DE-69120 Heidelberg, Germany [A.F., C.C.B., S.G., \\ R.H.S., K.B.]; and St. Joseph's Hospital, Jirapa, Upper West Region, Ghana [M.F.]
}

\begin{abstract}
The pathophysiology of kwashiorkor, a severe edematous manifestation of malnutrition, is still poorly understood. The syndrome is, however, known to be associated with alterations in redox metabolism. To further elucidate the role of oxidative stress in kwashiorkor, we carried out a longitudinal study on the major blood antioxidants at the St. Joseph's Hospital, Jirapa, Ghana. All kwashiorkor patients (K) were followed up for $20 \mathrm{~d}$. In comparison with local healthy controls (C), the plasma total antioxidant status was reduced to less than $50 \%$ in the patients (C, $0.87 \pm 0.21 \mathrm{mM} ; \mathrm{K}, 0.40 \pm 0.20 \mathrm{mM} ; p<0.001)$. Similarly, the major plasma antioxidant albumin $(\mathrm{C}, 40.9 \pm 2.5 \mathrm{~g} / \mathrm{L} ; \mathrm{K}$, $19.1 \pm 7.4 \mathrm{~g} / \mathrm{L} ; p<0.001)$ and erythrocyte glutathione $(\mathrm{C}, 2.39$ $\pm 0.28 \mathrm{mM} ; \mathrm{K}, 1.01 \pm 0.33 ; p<0.001)$ were decreased, whereas the levels of bilirubin and uric acid were not significantly altered. Nitrite and nitrate were found to be increased by a factor of 2 in kwashiorkor $(C, 120 \pm 46 \mu \mathrm{M} ; \mathrm{K}, 235 \pm 107$ $\mu \mathrm{M} ; p<0.001)$. Over the observation period, the trends of
\end{abstract}

\section{ABSTRACT}

albumin and glutathione levels were related to clinical outcome. These concentrations rose in patients who recovered and fell in patients who did not. Our study strongly supports the hypothesis that oxidative and nitrosative stress play a role in the pathophysiology of edematous malnutrition. Prophylactic and therapeutic strategies should aim at the careful correction of the reduced antioxidant status of the patients. (Pediatr Res 49: 237-243, 2001)

$\quad$ Abbreviations
ABTS, 2,2'-azino-di(3-ethylbenzothiazoline sulfonate)
DTNB, 5,5'-dithio-bis(2-nitrobenzoate)
GSH, reduced glutathione
NO, nitrogen monoxide
TAOS, total antioxidant status
PEM, protein-energy malnutrition

Severe malnutrition represents one of the most severe socioeconomic and health problems in the world. Clinically, protein-energy malnutrition (PEM) can be divided into three major forms: 1) marasmus, which is characterized by severe deficit of body mass; 2) kwashiorkor, an edematous form of malnutrition; and 3) marasmic kwashiorkor $(1,2)$.

The full clinical picture of kwashiorkor further includes skin lesions, red hair color, partial loss of hair, a fatty liver, apathy, and irritability; the syndrome is typically precipitated by infections. The clinical management of kwashiorkor is still highly insufficient with a mortality ranging between 10 and $50 \%$ (3-5). During the last $40 \mathrm{y}$, this situation has not significantly improved. This worrying constellation is based on the fact that our knowledge on pathophysiology and therapeutical interventions is highly inadequate.

Received January 27, 2000; accepted August 8, 2000.

Correspondence and reprint requests: Katja Becker, M.D., Interdisciplinary Research Center, Heinnide-Buff-Ring 26-32, DE-35392 Giessen, Germany.

Supported by the Deutsche Forschungs-gemeinschaft. The financial support provided by the Friedrich-Fischer Nachla $\beta$ of Heidelberg University is highly acknowledged.
As initially postulated by Golden and Ramdath (6), an imbalance between reactive oxygen species generated and the available antioxidant capacity may play a significant role in the pathophysiology of kwashiorkor. Over the last years, the syndrome was indeed shown to be associated with drastically decreased concentrations of glutathione, with low concentrations of vitamin E, carotene, selenium, and polyunsaturated fatty acids, with a reduced $\mathrm{NADPH} / \mathrm{NADP}^{+}$ratio, and with low glutathione peroxidase and elevated glutathione- $S$ transferase activity (5-9). Furthermore, high concentrations of circulating ferritin and hepatic iron have been reported as signs of liver injury (6).

The longitudinal study presented here was carried out to gain further insight into the redox processes characterizing kwashiorkor. Based on our further understanding of this oxidative stress syndrome, new prophylactic and therapeutic measures may be developed (10). To obtain a parameter summarizing the various single plasma antioxidants, we determined the TAOS (11) in kwashiorkor patients. Together with the TAOS, three of its major single components, namely albumin, bilirubin, and 
uric acid, were measured. Infection, a main feature of kwashiorkor, represents one of the most important stimuli of inducible NO synthase activity $(12,13)$. Furthermore, because oxidative stress and nitrosative stress are closely linked and NO as a vasoactive and potentially toxic metabolite may contribute to the pathophysiology of kwashiorkor, we also determined plasma concentrations of nitrite and nitrate, the stable end products of NO metabolism $(13,14)$.

\section{METHODS}

\section{Patients}

Children admitted to the Nutrition Unit of St. Joseph's Hospital, Jirapa, Upper West Region, Ghana, were physically examined. Clinical and anthropometric data were taken and related to established standards (15). On admission, a venous EDTA blood sample not exceeding $2 \mathrm{~mL}$ was taken for routine parasitologic and hematologic analyses as well as for the biochemical parameters determined in this study. Inclusion criteria for the kwashiorkor group were defined as follows: approximately 60 to $80 \%$ of normal weight/age standards, generalized edema, skin lesions, and hair loss and/or discoloration. Anthropometry, described in terms of the NCHS standards (1), and clinical status of the patients on admission and follow-up days are detailed in Table 1 , a and $\mathrm{b}$. Because kwashiorkor is typically characterized by hypalbuminemia and hypoglutathionemia $(6,8)$, plasma albumin $(<30 \mathrm{~g} / \mathrm{L})$ and glutathione concentrations $(<0.4 \mathrm{mM}$ in whole blood corresponding to $<1.2 \mathrm{mM}$ in erythrocytes) were added to the inclusion criteria. A nephrotic syndrome in the patients was ruled out by the absence of proteinuria. According to these criteria, only children with the full clinical picture of kwashiorkor were included in the study. Patients were clinically and biochemically followed up for $20 \mathrm{~d}$. It should be emphasized

Table 1a. Anthropometric data and overall clinical status of the kwashiorkor patients on admission

\begin{tabular}{|c|c|c|c|c|c|c|c|}
\hline $\begin{array}{c}\text { Patient } \\
\text { No. }\end{array}$ & Gender & $\begin{array}{l}\text { Age } \\
\text { (mo) }\end{array}$ & $\begin{array}{c}\text { Height } \\
(\mathrm{cm})\end{array}$ & $\begin{array}{c}\text { Weight } \\
(\mathrm{kg})\end{array}$ & $\begin{array}{c}Z \text { score } \\
(\mathrm{wt} / \mathrm{ht})\end{array}$ & $\begin{array}{l}Z \text { score } \\
\text { (ht/age) }\end{array}$ & $\begin{array}{l}\text { Status on } \\
\text { admission }\end{array}$ \\
\hline 1 & $\mathrm{~F}$ & 24 & 77 & 7.7 & -2.6 & -2.9 & 2 \\
\hline 2 & $\mathrm{~F}$ & 60 & 98 & 12.0 & -2.1 & -2.4 & 1 \\
\hline 3 & $\mathrm{~F}$ & 36 & 78 & 6.0 & -4.7 & -4.3 & 2 \\
\hline 4 & M & 12 & 68 & 6.0 & -2.6 & -3.0 & 2 \\
\hline 5 & M & 36 & 93 & 10 & -3.0 & -0.5 & 2 \\
\hline 6 & $\mathrm{~F}$ & 26 & 64 & 7.0 & -0.4 & -6.7 & 2 \\
\hline 7 & F & 30 & 76 & 7.5 & -2.6 & -3.9 & 2 \\
\hline 8 & M & 32 & 79 & 9.2 & -1.9 & -3.3 & 1 \\
\hline 9 & $\mathrm{~F}$ & 60 & 90 & 10.2 & -2.5 & -4.2 & 1 \\
\hline 10 & M & 27 & 80 & 9.3 & -1.4 & -2.4 & 2 \\
\hline 11 & M & 30 & 82 & 10.5 & -0.9 & -2.4 & 1 \\
\hline 12 & M & 18 & 75 & 11.0 & 1.5 & -2.5 & 3 \\
\hline 13 & F & 36 & 74 & 8.2 & -1.3 & -5.4 & 3 \\
\hline 14 & $\mathrm{~F}$ & 38 & 88 & 11.0 & -1.4 & -1.9 & 1 \\
\hline 15 & $\mathrm{~F}$ & 30 & 79 & 9.0 & -1.6 & -3.0 & 3 \\
\hline 16 & $\mathrm{~F}$ & 60 & 85 & 10.0 & -1.8 & -5.3 & 3 \\
\hline 17 & $\mathrm{~F}$ & 36 & 90 & 10.9 & -1.8 & -1.1 & 1 \\
\hline 18 & $\mathrm{~F}$ & 24 & 71 & 5.7 & -3.6 & -4.7 & 2 \\
\hline 19 & $\mathrm{~F}$ & 28 & 78 & 8.2 & -2.2 & -2.9 & 1 \\
\hline
\end{tabular}

$Z$ scores (for weight/height and height/age) refer to the NCHS/WHO normalized reference values. Overall clinical impression on $\mathrm{d} 1: 1=$ poor, $2=$ very poor, $3=$ apathic. that these stringent inclusion criteria enhance the reliability and valid interpretation of the data but also explain the relatively high lethality of this particular group of patients (8).

The kwashiorkor group $(\mathrm{K})$ was compared with a control group (C) consisting of healthy local children: $n=15$; median age, $21 \mathrm{mo}$; median weight for age, $86.1 \%$. The children were taken by their mothers to the Outpatient Department of the hospital for a routine checkup. The study was explained to the mothers who all gave their oral consent and assisted during physical examination and blood taking.

As a diet, the control children received the local mixed food consisting mainly of yam, tomatoes, rice, and maize. The kwashiorkor patients were treated for infections, and patients with an $\mathrm{Hb}$ concentration of $<5 \mathrm{~g} / 100 \mathrm{~mL}$ received a blood transfusion and were excluded from the study. Patients received $150 \mathrm{~mL}$ of a rehabilitation formula $(50 \mathrm{~g} / \mathrm{L}$ skimmed milk powder, $30 \mathrm{~g} / \mathrm{L}$ sugar, and $30 \mathrm{~g} / \mathrm{L}$ oil) three times daily. Because the mothers usually stayed in the hospital with their children, the patients also received small amounts of local food. Blood was taken in the morning in all groups of children.

The study was explained to the parents of the patients in their respective native language, and their oral consent was obtained. The ethical aspects of the study were approved by the Ethics Committee of the Diocesan Health Committee of Wa Diocese, Wa, Ghana, and the Medical Regional Directorate, Upper West Region, Ghana.

\section{Materials}

Reagents obtained from Boehringer (Mannheim, Germany), Sigma Chemical Co. (St. Louis, MO, U.S.A.), and Merck (Darmstadt, Germany) were of the highest purity available. Recombinant human glutathione reductase produced as described (16) was used for assaying total glutathione.

\section{Analytical Methods}

One aliquot of fresh EDTA blood was immediately frozen for analysis of the parameters in full blood. A second aliquot was used for glutathione determination (see below). The remaining blood was centrifuged to separate plasma from red blood cells; the plasma was then immediately frozen, red cells were washed twice in PBS and then frozen. All samples were stored in Ghana and during the transport at $\leq-20^{\circ} \mathrm{C}$ (in a refrigerator and on dry ice, respectively). Blood samples of patients and controls were treated identically. Glutathione, TAOS, and NO end products were determined at the Center of Biochemistry, Heidelberg University, Germany (see below). Total protein, albumin, bilirubin, and uric acid were determined at the Institute of Clinical Chemistry, Ulm University, by use of standard laboratory methods.

Glutathione. Total glutathione in whole blood was measured by a procedure adapted to the needs of tropical medicine as described (17). Briefly, $0.2 \mathrm{~mL}$ of fresh EDTA blood was mixed with $0.6 \mathrm{~mL}$ of $5 \%$ sulfosalicylic acid. The sample was centrifuged (10 min, 10,000 g), and the supernatant was stored at $-20^{\circ} \mathrm{C}$ until analysis. For glutathione determination, $10 \mu \mathrm{L}$ of supernatant was assayed in a total volume of $1 \mathrm{~mL}$ of phosphate buffer containing $0.6 \mathrm{mM}$ DTNB, $0.5 \mathrm{U} / \mathrm{mL}$ gluta- 
Table 1b. Weight as well as status of edema and skin lesions of the kwashiorkor patients on admission and the four follow-up dates

\begin{tabular}{|c|c|c|c|c|c|c|c|c|c|c|c|c|c|c|c|c|}
\hline \multirow{2}{*}{$\begin{array}{c}\text { Patient } \\
\text { No. }\end{array}$} & \multicolumn{5}{|c|}{ Weight $(\mathrm{kg})$} & \multicolumn{5}{|c|}{ Edema } & \multicolumn{5}{|c|}{ Skin lesions } & \multirow[b]{2}{*}{ Comments } \\
\hline & 1 & 4 & 8 & 14 & 20 & 1 & 4 & 8 & 14 & 20 & 1 & 4 & 8 & 14 & 20 & \\
\hline 1 & 7.7 & 8.3 & 7.9 & 7.8 & 7.5 & ++ & ++ & + & + & + & + & + & + & + & $\varnothing$ & Discharged on d 17 \\
\hline 3 & 6.0 & - & - & - & - & ++ & - & - & - & - & +++ & - & - & - & - & Died on $\mathrm{d} 4$ \\
\hline 4 & 6.0 & 5.9 & - & - & - & + & + & - & - & - & + & + & - & - & - & Died on $\mathrm{d} 4$ \\
\hline 5 & 10 & 9.0 & - & - & - & ++ & ++ & - & - & - & ++ & ++ & - & - & - & Died on $\mathrm{d} 2$ \\
\hline 6 & 7.0 & 6.0 & 6.5 & - & - & ++ & ++ & ++ & - & - & +++ & +++ & +++ & - & - & Died on $\mathrm{d} 12$ \\
\hline 8 & 9.2 & 10.2 & 10.3 & 11.1 & 11.1 & + & ++ & + & + & $\varnothing$ & + & + & + & + & $\varnothing$ & Much improved from d 15 \\
\hline 9 & 10.2 & 9.5 & 9.0 & - & - & ++ & ++ & + & - & - & + & + & ++ & - & - & Died on day 13 \\
\hline 10 & 9.3 & 10.2 & 9.9 & 10.2 & 10.5 & + & + & + & $\varnothing$ & $\varnothing$ & + & $\varnothing$ & $\varnothing$ & $\varnothing$ & $\varnothing$ & Much improved from day 12 \\
\hline 11 & 10.5 & 10.8 & 10.6 & - & - & + & + & ++ & - & - & + & + & + & - & - & Mother took child home day 13 \\
\hline 12 & 11.0 & 9.6 & 10.1 & 9.4 & - & + & + & ++ & ++ & - & ++ & ++ & ++ & ++ & - & Died on day 15 \\
\hline 13 & 8.2 & 8.2 & 8.4 & 8.0 & 8.4 & + & + & $\varnothing$ & $\varnothing$ & $\varnothing$ & + & + & + & + & $\varnothing$ & Improved on day 18 \\
\hline 14 & 11.0 & 10.0 & - & - & - & ++ & + & - & - & - & ++ & ++ & - & - & - & Died on day 6 \\
\hline 19 & 8.2 & 8.6 & 8.8 & 8.2 & 7.7 & ++ & ++ & ++ & ++ & ++ & + & + & + & ++ & +++ & Much worse on day 20 \\
\hline
\end{tabular}

Edema and skin lesion marks: $\varnothing=$ not present; $+=$ mild; $++=$ moderate; $+++=$ severe.

thione reductase, and $0.3 \mathrm{mM}$ NADPH. The reduction of DTNB was followed spectrophotometrically at $412 \mathrm{~nm}$ and $25^{\circ} \mathrm{C}$ and related to a calibration curve. The concentration of erythrocyte glutathione was estimated on the basis of whole blood glutathione and hematocrit.

TAOS. The TAOS was measured by the ABTS assay, which is based on the capacity of plasma to scavenge the $\mathrm{ABTS}^{+}$ radical (11). In the assay, metmyoglobin is oxidized by $\mathrm{H}_{2} \mathrm{O}_{2}$; the produced ferrylmyoglobin then oxidizes ABTS to the $\mathrm{ABTS}^{+}$radical that shows a characteristic long wavelength absorption spectrum. In the presence of antioxidants like the Trolox standard used or blood plasma, the radical is scavenged dose dependently. The absorbance was first measured by mixing $1 \mathrm{~mL}$ of a chromogene solution (PBS buffer containing $7.45 \mu \mathrm{M}$ horse metmyoglobin and $745 \mu \mathrm{M}$ ABTS) with $20 \mu \mathrm{L}$ of the plasma sample. Exactly $3 \mathrm{~min}$ after adding $200 \mu \mathrm{L}$ of the substrate $\left(1.5 \mathrm{mM} \mathrm{H}_{2} \mathrm{O}_{2}\right.$ in PBS buffer) at $25^{\circ} \mathrm{C}$, the final absorption at $600 \mathrm{~nm}$ was measured. The TAOS were computed by relating the data to a $0.5-\mathrm{mM}$ Trolox standard solution according to the following equations: TAOS $=\mathrm{F} \times\left(\Delta \mathrm{A}_{\text {blank }}-\right.$ $\left.\Delta \mathrm{A}_{\text {standard }}\right)[\mathrm{mM}] ; \mathrm{F}=$ standard concentration $/\left(\Delta \mathrm{A}_{\text {blank }}-\right.$ $\left.\Delta \mathrm{A}_{\text {standard }}\right)$.

Nitrite and nitrate. NO concentrations in plasma were assayed according to Grisham et al. (18) with slight modifications. This method is based on the indirect determination of
NO by spectrophotometric measurement of its stable metabolic products, nitrite and nitrate. Two hundred microliters of a reaction mixture $(50 \mathrm{mM}$ HEPES, $\mathrm{pH} 7.4$, containing $5 \mu \mathrm{M}$ FAD, $0.2 \mathrm{U} / \mathrm{mL}$ nitrate reductase, and $0.1 \mathrm{mM} \mathrm{NADPH}$ ) was mixed with $30 \mu \mathrm{L}$ of plasma and incubated for $30 \mathrm{~min}$ at $37^{\circ} \mathrm{C}$. Then, $2 \mu \mathrm{L}$ of lactate dehydrogenase $(1500 \mathrm{U} / \mathrm{mL})$ and $25 \mu \mathrm{L}$ of pyruvate $(100 \mathrm{mM})$ were added to each cuvette and incubated for another $10 \mathrm{~min}$ at $37^{\circ} \mathrm{C}$. Six hundred microliters of premixed Griess reagent (consisting of equal volumes of $2 \%$ sulfanilamide and $0.2 \% N$-(1-naphthyl)ethylene-diaminedihydrochloride, both in 5\% phosphoric acid) was added and after a 10-min incubation at room temperature, the absorbance of each sample was read at $543 \mathrm{~nm}$. Plasma NO concentrations were calculated on the basis of a calibration curve with $\mathrm{KNO}_{3}$ standards.

\section{Statistics}

For intercohortal and intracohortal analyses, respectively, the unpaired and paired $t$ tests were applied.

\section{RESULTS}

In the present longitudinal study, different biochemical redox parameters were determined in children suffering from the malnutrition syndrome kwashiorkor. All parameters were mea-

Table 2. TAOS in the plasma of kwashiorkor patients $(n=19)$ and healthy controls $(n=15)$

\begin{tabular}{|c|c|c|c|c|c|c|c|}
\hline & \multirow{2}{*}{$\begin{array}{l}\text { Controls } \\
\text { only d } 1\end{array}$} & \multicolumn{6}{|c|}{ Kwashiorkor } \\
\hline & & & d 1 & d 4 & d 8 & d 14 & d 20 \\
\hline \multirow[t]{2}{*}{ TAOS $[\mathrm{mM}]$} & $0.87 \pm 0.21$ & total & $0.40 \pm 0.20^{* *}$ & $0.32 \pm 0.21 * *$ & $0.38 \pm 0.25^{* *}$ & $0.49 \pm 0.26^{* *}$ & $0.42 \pm 0.24 * *$ \\
\hline & & fatal & $0.41 \pm 0.24$ & $0.38 \pm 0.28$ & $0.45 \pm 0.34$ & $0.47 \pm 0.33$ & $0.47 \pm 0.33$ \\
\hline
\end{tabular}

Given are mean values $\pm \mathrm{SD} ; * p<0.05 ; * * p<0.001 ; p$ values compare in the line "total" controls with kwashiorkor patients and in the line "fatal" patients who recovered with fatal cases. 
sured on admission (d 1) and a follow-up period of $20 \mathrm{~d}(\mathrm{~d} 4$, 8,14 , and 20). The obtained data were compared with a group of healthy local controls and are summarized in Tables 2-4. To estimate whether the biochemical parameters were related to the course of illness, the data of patients who recovered $(n=$ $11)$ and of those with fatal outcome $(n=8)$ were processed also separately. As a parameter summarizing the numerous antioxidative factors in plasma, we determined the TAOS. In parallel, different parameters contributing to the TAOS, namely uric acid, bilirubin, total protein, and albumin, were measured. Full blood glutathione concentrations were determined as an indicator of disease severity. Furthermore, the plasma nitrite and nitrate concentrations as indicators of $\mathrm{NO}$ levels in plasma were measured.

The TAOS was found to be drastically reduced in kwashiorkor. This phenomenon was detected throughout the observation period (Table 2). The plasma antioxidants bilirubin and uric acid were not significantly altered and did not change over the observation period. However, a slight increase in bilirubin concentration was detected in the patients with fatal outcome in comparison with those who survived. This elevated value was, however, still within the normal range of bilirubin levels of this particular age group.

As described in previous studies $(6,8,19)$, the erythrocyte glutathione concentrations were significantly reduced in kwashiorkor and were related to the clinical outcome. In fact, over the observation period, glutathione levels rose in patients who recovered and dropped or were constant in patients who did not (Table 3). Similar features and dynamics were observed for the parameters total plasma protein and albumin.

Results on plasma NO concentrations are given in Table 4. Nitrite and nitrate levels were indeed found to be increased in kwashiorkor by a factor of almost 2 . As for the TAOS, similar values were detected throughout the observation period.

\section{DISCUSSION}

More than 10 y ago, Golden and Ramdath (6) postulated the involvement of oxidative stress in the severe edematous malnutrition syndrome kwashiorkor. Since then, evidence for the role of reactive oxygen species (ROS) in the pathophysiology has increased $(5,8,9)$. The lethality of kwashiorkor is still unacceptably high, and successful measures for prevention have not yet been developed. Our inadequate knowledge of the metabolic processes taking place in kwashiorkor has up to now been limiting for improving this situation. To gain more insight into the role of ROS and reactive nitrogen species (NOS) in kwashiorkor, the present study was carried out.

Glutathione. The erythrocyte glutathione concentrations were drastically reduced in kwashiorkor patients and were clearly related to the clinical outcome. After $2 \mathrm{wk}$, the concentrations reached normal levels in the patients who survived and dropped or were constantly low in the patients with lethal outcome. This phenomenon has been described in previous studies $(6,8,19)$. Apart from the multiple functions of glutathione in the cellular redox equilibrium, many of which are discussed below, its beneficial effects on cell membrane electrolyte transport may play a particularly important role in the pathophysiology of kwashiorkor. As demonstrated by Forrester et al. (20), reduction of the intracellular glutathione content of normal red cells to values characteristic of edematous malnutrition reproduced the abnormalities of sodium content and flux observed in kwashiorkor. Also, during clinical recovery from severe malnutrition, sodium pump activity is likely to represent a critical parameter (21).

TAOS. Our data indicate that the TAOS in children suffering from kwashiorkor is reduced to less than $50 \%$ of local control values. When comparing the TAOS of our patients with healthy European term babies at the age of $5 \mathrm{~d}$ [TAOS $=1.50$ $+0.14 \mathrm{mM}$ (11)], only $27 \%$ of this antioxidant status is reached. This result underlines the importance of ROS in the malnutrition syndrome as well as previous data of different research groups who determined various single parameters contributing to the plasma TAOS of a patient $(5,6,8)$.

The TAOS is composed of the antioxidant capacity of total protein (85\%; mainly albumin but also transferrin and ceruloplasmin), uric acid (12\%), bilirubin (4\%), carotinoids (3\%), tocopherols $(1 \%)$, and ascorbic acid $(1 \%)(22,23)$. (Because these data given in Ref. 22 had been deduced from different sources, they do not sum up to exactly $100 \%$.) These different antioxidants do act via distinct mechanisms. On the basis of their iron-binding capacity, an inhibition of iron-dependent hydroxyl radical formation has been established for transferrin and ceruloplasmin (24). Albumin also binds plasma iron, copper, and FFA, thus preventing peroxidation processes $(24,25)$.

Table 3. Total glutathione concentrations in erythrocytes as well as total protein and albumin concentrations in plasma of kwashiorkor patients $(n=19)$ and healthy controls $(n=15)$

\begin{tabular}{|c|c|c|c|c|c|c|c|}
\hline & \multirow{2}{*}{$\begin{array}{l}\text { Controls } \\
\text { only d } 1\end{array}$} & \multicolumn{6}{|c|}{ Kwashiorkor } \\
\hline & & & d 1 & d 4 & d 8 & d 14 & d 20 \\
\hline \multirow[t]{2}{*}{ Glutathione [mM] } & $2.39 \pm 0.28$ & total & $1.01 \pm 0.33^{* *}$ & $0.90 \pm 0.26^{* *}$ & $1.20 \pm 0.83^{* *}$ & $1.61 \pm 1.45^{*}$ & $1.38 \pm 0.87 * *$ \\
\hline & & fatal & $0.86 \pm 0.14 *$ & $0.81 \pm 0.24$ & $0.84 \pm 0.35^{*}$ & $0.88 \pm 0.35^{*}$ & $0.88 \pm 0.35^{*}$ \\
\hline \multirow[t]{2}{*}{ Total protein $[\mathrm{g} / \mathrm{L}]$} & $69.2 \pm 4.8$ & total & $42.3 \pm 9.6^{* *}$ & $41.6 \pm 8.2^{* *}$ & $39.5 \pm 11.2 * *$ & $43.9 \pm 13.8^{* *}$ & $47.9 \pm 16.9^{* *}$ \\
\hline & & recovered & $46.7 \pm 10.2$ & $45.5 \pm 8.8$ & $42.9 \pm 14.3$ & $52.0 \pm 15.3$ & $58.8 \pm 16.4$ \\
\hline \multirow{2}{*}{ Albumin $[\mathrm{g} / \mathrm{L}]$} & & recovered & $21.2 \pm 8.8$ & $20.1 \pm 7.4$ & $21.3 \pm 9.1$ & $23.4 \pm 10.5$ & $25.7 \pm 10.1$ \\
\hline & & fatal & $16.6 \pm 4.4$ & $16.0 \pm 3.0$ & $15.0 \pm 2.8$ & $15.7 \pm 3.1^{*}$ & $15.7 \pm 3.1^{*}$ \\
\hline
\end{tabular}

Given are mean values $\pm \mathrm{SD} ; * p<0.05 ; * * p<0.001 ; p$ values compare in the line "total" controls with kwashiorkor patients and in the line "fatal" patients who recovered with fatal cases. 
Table 4. Plasma concentrations of the stable NO end products nitrite and nitrate in kwashiorkor patients $(n=19)$ and healthy controls $(n=15)$

\begin{tabular}{|c|c|c|c|c|c|c|c|}
\hline & \multirow{2}{*}{$\frac{\text { Controls }}{\text { only d } 1}$} & \multicolumn{6}{|c|}{ Kwashiorkor } \\
\hline & & & d 1 & d 4 & d 8 & d 14 & d 20 \\
\hline \multirow[t]{2}{*}{$\mathrm{NO}[\mu \mathrm{M}]$} & $120 \pm 46$ & total & $235 \pm 107 * *$ & $215 \pm 97 * *$ & $231 \pm 86^{* *}$ & $237 \pm 103 * *$ & $240 \pm 127^{* *}$ \\
\hline & & fatal & $229 \pm 64$ & $223 \pm 75$ & $229 \pm 73$ & $248 \pm 96$ & $248 \pm 96$ \\
\hline
\end{tabular}

Given are mean values $\pm \mathrm{SD} ; * p<0.05 ; * *<<0.001 ; p$ values compare in the line "total" controls with kwashiorkor patients and in the line "fatal" patients who recovered with fatal cases.

In addition, a glutathione-linked thiol peroxidase activity (26) and a carbon radical scavenging activity (27) have been described for albumin as well as its capability to scavenge peroxyl radicals and to decrease lipoxygenase activity (25). As reported recently, the antioxidant properties of serum albumin are impaired by free radicals (28). Albumin is certainly the most severely reduced plasma protein in kwashiorkor. This lack of albumin in combination with increased concentrations of circulating ferritin and hepatic iron can result in a vicious cycle. This cycle may be worsened by an insufficient intake of sulfur-containing amino acids leading to inadequate glutathione synthesis, by liver damage, and by the infections characterizing kwashiorkor. Our data indicate that apart from albumin, other plasma proteins contributing to the TAOS are also reduced. This is supported by studies demonstrating decreased levels of transferrin and ceruloplasmin in kwashiorkor (29). It should, however, also be noted that the extrapolation of a TAOS to the in vivo situation is limited. Indeed, the TAOS assay can only estimate the overall antioxidant status in the plasma of a patient. Among others, a major point of criticism is the fact that the scavenging of only one reactive oxygen species, the nonphysiologic ABTS radical, is studied, whereas other ROS and NOS are not taken into account (30).

Bilirubin and uric acid. In addition to albumin, we determined two more parameters contributing approximately 4 and $12 \%$, respectively, to the plasma antioxidant status, namely bilirubin and uric acid (22). Bilirubin has been shown to scavenge peroxyl radicals and peroxynitrite and is known to prevent the oxidation of aromatic amino acid residues, the formation of protein carbonyl groups, and protein fragmentation $(31,32)$. Recently, a neuroprotective role of bilirubin also has been postulated (33). As shown for neonatal erythrocytes, physiologic concentrations of bilirubin protect against oxidative stress.

Uric acid, ranking as position three of the plasma antioxidants, can act as a singlet oxygen and radical scavenger (34, 35). Complex formation between uric acid and iron ions has been shown to inhibit ascorbate oxidation and lipid peroxidation (36).

In our study, both parameters, bilirubin and uric acid, were found to be within the normal range in kwashiorkor; neither of them differed significantly between patients and controls. However, in patients who recovered, bilirubin concentrations were lower than in fatal cases, and uric acid concentrations decreased slightly over time. Our data support the findings of Garrow and Pike (37) who described a correlation between slightly elevated bilirubin concentrations and negative progno- sis in malnutrition. However, because the absolute increase in bilirubin concentrations is rather discrete, the data of Sakr et al. (38) who determined normal bilirubin levels in kwashiorkor have also been validated. As far as other plasma antioxidants are concerned, it should be mentioned that vitamin E deficiency is considered a major feature of kwashiorkor (6). In a study carried out in Nigeria, plasma $\alpha$-tocopherol, total tocopherol, and the tocopherol-lipid ratio were decreased to approximately $50 \%$ (7). Although different studies on vitamin A status do not provide a completely uniform picture, vitamin A deficiency often accompanies severe malnutrition $(6,7,39,40)$.

Taking these aspects together, our results support the hypothesis that kwashiorkor is not simply caused by protein deficiency but rather by a certain combination of altered parameters including reduced concentrations of antioxidants, above all albumin. The fact that albumin is not only an osmotically active plasma constituent and essential carrier molecule but also one of the most important plasma antioxidants (25) puts this protein again in the center of the probable pathophysiologic constellation.

NO. Apart from the TAOS, our study aimed at determining the concentration of $\mathrm{NO}$ in kwashiorkor. Among the many prooxidative effects of $\mathrm{NO}$, protein modification by nitrosylation or oxidation of SH groups has been reported, leading e.g. to the inactivation of glutathione reductase, superoxide dismutase, and glutathione peroxidase (41). Also, depletion of intracellular glutathione (42), formation of peroxynitrite in interaction with the superoxide anion, DNA damage, and induction of apoptotic and necrotic cell death are established effects of NO $(12,42,43)$. NO plays an important role in the regulation of vascular tone and endothelial function (44), which, with respect to the pathophysiology of kwashiorkor, is an important feature. Excessive NO production is involved in circulatory failure and cytotoxicity (13). Moderate NO production, however, can be protective by virtue of its vasodilating, antithrombotic, and leukocyte adhesion inhibitory effects (45, 46).

According to our results, $\mathrm{NO}$ concentrations are increased in kwashiorkor patients by approximately a factor of 2. This observation is in line with the findings of Golden (5) who recently described increased NO production measured as urinary nitrate excretion. The causes leading to these enhanced NO levels remain to be elucidated. Apart from the induction of NO production by infections, cardiovascular causes should be considered. In kwashiorkor, NO may contribute to the GSH levels by directly reacting with glutathione and thioredoxin or by inhibiting antioxidant enzymes like glutathione reductase 
$(12,41)$. Glutathione, which is drastically decreased in kwashiorkor, was shown to play a crucial role in protecting from NO-induced cytotoxicity (47). In addition, as established by Park and Aust (48), GSH depletion and increased iron concentrations do facilitate the induction of inducible NO synthase (iNOS). However, NO may also play a beneficial role in the pathophysiologic constellation studied. Apart from antiinflammatory and antioxidant activity, NO has been shown to exert positive effects on mild liver injury (49), and, as demonstrated by Sergent et al. (50), NO acts as an antioxidant in ironmediated oxidative stress in rat hepatocytes. NO can be beneficial in physiologic concentrations but toxic in excess $(12,46)$; its metabolic role in kwashiorkor will have to be clarified.

Conclusion. Our study strongly supports the hypothesis that oxidative and nitrosative stress play a role in the pathophysiology of the malnutrition syndrome kwashiorkor. The fact that the alterations in TAOS and NO concentrations were detected over the observation period of $20 \mathrm{~d}$, more pronounced than for glutathione and albumin, suggests that the disturbances in the redox equilibrium of kwashiorkor patients are long lasting. Previous studies indicate that leukotriene $\mathrm{C}_{4}$ synthesis is enhanced in kwashiorkor, whereas leukotriene $\mathrm{B}_{4}$ synthesis is impaired (51). This constellation is likely to contribute to the pathophysiologic characteristics of kwashiorkor, particularly the generalized edema and the susceptibility to infections. Because leukotriene metabolism is known to be redox regulated, our findings contribute to the explanation of the above findings.

In kwashiorkor, prophylactic and therapeutic strategies should aim at treating the infections, controlling the hydration state, and carefully correcting the reduced antioxidant capacity and, in direct connection, the protein deficiency. The great challenge in developing an effective therapy that is able to break the underlying vicious cycle is the fact that kwashiorkor patients suffer from severe liver dysfunction, thus reacting very sensitively to the administration of proteins and various antioxidant compounds.

Acknowledgments. The authors thank Prof. H.-J. Gro $\beta$ and Prof. A. Grünert, Department of Clinical Chemistry, Ulm University, for their support. We also thank I. König and Dr. R. Iozef for their excellent technical help.

\section{REFERENCES}

1. WHO 1999 Management of Severe Malnutrition: A Manual for Physicians and Other Senior Health Workers. World Health Organization, Geneva

2. Suskind D, Murphy KK, Suskind RM 1990 The malnourished child: an overview. In: Suskind RM, Lewinter-Suskind L (eds) The Malnourished Child. Raven Press, New York, pp 1-22

3. Erinoso HO, Akinbami FO, Akinyinka OO 1993 Prognostic factors in severely malnourished hospitalized Nigerian children. Anthropometric and biochemical factors. Trop Geogr Med 45:290-293

4. Golden MH 1994 Issues in kwashiorkor. Lancet 343:292

5. Golden MH 1998 Oedematous malnutrition. Br Med Bull 54:433-444

6. Golden MH, Ramdath D 1987 Free radicals in the pathogenesis of kwashiorkor. Proc Nutr Soc 46:53-68

7. Becker K, Bötticher D, Leichsenring M 1994 Antioxidant vitamins in malnourished Nigerian children. Int J Vitam Nutr Res 64:306-310

8. Becker K, Leichsenring M, Gana L, Bremer HJ, Schirmer RH 1995 Glutathione and associated antioxidant systems in protein energy malnutrition: results of a study in Nigeria. Free Radic Biol Med 18:257-263

9. Leichsenring M, Sütterlin N, Less S, Bäumann K, Anninos A, Becker K 1995 Polyunsaturated fatty acids in erythrocyte and plasma lipids of children with severe protein-energy malnutrition. Acta Paediatr 84:516-520

10. Aruoma OI 1994 Nutrition and health aspects of free radicals and antioxidants. Food Chem Toxicol 32:671-683
11. Miller NJ, Rice-Evans C, Davies MJ, Gopinathan V, Milner A 1993 A novel method for measuring antioxidant capacity and its application to monitoring the antioxidant status in premature neonates. Clin Sci 84:407-412

12. Kröncke KD, Fehsel K, Kolb-Bachofen V 1997 Nitric oxide: cytotoxicity versus cytoprotection-how, why, when, and where? Nitric Oxide 1:107-120

13. Stoclet JC, Muller B, Andriantsitohaina R, Kleschyov A 1998 Overproduction of nitric oxide in pathophysiology of blood vessels. Biochemistry 63:826-832

14. Wink DA, Hanbauer I, Laval F, Cook JA, Krishna MC, Mitchell JB 1994 Nitric oxide protects against the cytotoxic effects of reactive oxygen species. Ann N Y Acad Sci 738:265-278

15. Stuart HC, Stevenson SS 1987 Growth and development. In: Behrman RE, Vaughan VS (eds) Textbook of Pediatrics. WB Saunders, Philadelphia, pp 6-35

16. Nordhoff A, Bücheler US, Werner D, Schirmer RH 1993 Folding of the four domains and dimerization are impaired by the Gly446- $>$ Glu exchange in human glutathione reductase. Implications for the design of antiparasitic drugs. Biochemistry 32:4060 4066

17. Becker K, Gui M, Traxler A, Kirsten C, Schirmer RH 1994 Redox processes in malaria and other parasitic diseases. Determination of intracellular glutathione. Histochemistry 102:389-395

18. Grisham MB, Johnson GG, Lancaster Jr JR 1996 Quantitation of nitrate and nitrite in extracellular fluids. Methods Enzymol 268:237-246

19. Golden MH, Patrick J, Jackson AA, Picou DI 1975 Serum-albumin in oedematous malnutrition. Lancet 2:1044

20. Forrester T, Golden M, Brand S, Swales J 1990 Reduction in vitro of red cell glutathione reproduces defects of cellular sodium transport seen in oedematous malnutrition. Eur J Clin Nutr 44:363-369

21. Patrick J 1977 Death during recovery from severe malnutrition and its possible relationship to sodium pump activity in the leukocyte. BMJ 1:1051-1054

22. Kanofsky JR 1990 Quenching of singlet oxygen by human plasma. Photochem Photobiol 51:299-303

23. Rice-Evans C, Miller NJ 1994 Total antioxidant status in plasma and body fluids. Methods Enzymol 234:279-293

24. Loban A, Kime R, Powers H 1997 Iron-binding antioxidant potential of plasma albumin. Clin Sci 93:445-451

25. Halliwell B 1988 Albumin-an important extracellular antioxidant? Biochem Pharmacol 37:569-571

26. Cha MK, Kim ICH 1996 Glutathione-linked thiol peroxidase activity of human serum albumin: a possible antioxidant role of serum albumin in blood plasma. Biochem Biophys Res Commun 222:619-625

27. Soriani M, Pietraforte D, Minetti M 1994 Antioxidant potential of anaerobic human plasma: role of serum albumin and thiols as scavengers of carbon radicals. Arch Biochem Biophys 312:180-188

28. Bourdon E, Loreau N, Blache D 1999 Glucose and free radicals impair the antioxidant properties of serum albumin. FASEB J 13:233-244

29. Subotzky EF, Heese HD, Sive AA, Dempster WS, Sacks R, Malan H 1992 Plasma zinc, copper, selenium, ferritin, and whole blood manganese concentrations in children with kwashiorkor in the acute stage and during refeeding. Ann Trop Paediatr 12:13-22

30. Strube M, Haenen GR, Van Den Berg H, Bast A 1997 Pitfalls in a method for assessment of total antioxidant capacity. Free Radic Res 26:515-521

31. Stocker R, Glazer AN, Ames BN 1987 Antioxidant activity of albumin-bound bilirubin. Proc Natl Acad Sci USA 84:5918-5922

32. Minetti M, Mallozzi C, Di Stasi AM, Pietraforte D 1998 Bilirubin is an effective antioxidant of peroxynitrite-mediated protein oxidation in human blood plasma. Arch Biochem Biophys 352:165-174

33. Dore S, Takahashi M, Ferris CD, Hester LD, Guastella D, Snyder SH 1999 Bilirubin, formed by activation of heme oxygenase- 2 , protects neurons against oxidative stress injury. Proc Natl Acad Sci USA 96:2445-2450

34. Ames BN, Cathcart R, Schwiers E, Hochstein P 1981 Uric acid provides an antioxidant defense in humans against oxidant- and radical-caused aging and cancer: a hypothesis. Proc Natl Acad Sci USA 78:6858-6862

35. Smith RC, Lawing L 1983 Antioxidant activity of uric acid and 3- $N$-ribosyluric acid with unsaturated fatty acids and erythrocyte membranes. Arch Biochem Biophys 223:166-172

36. Davies KJ, Sevanian A, Muakkassah-Kelly SF, Hochstein P 1986 Uric acid-iron ion complexes. A new aspect of the antioxidant functions of uric acid. Biochem $\mathrm{J}$ 235:747-754

37. Garrow JS, Pike MC 1967 The short-term prognosis of severe primary infantile malnutrition. BMJ 21:155-165

38. Sakr R, el-Hawary MF, el-Zawahry K, Nasr H, Samuel S 1969 Studies on total, free, and ester cholesterols and total bilirubin in kwashiorkor. J Egypt Med Assoc 52:117-128

39. Smith FR, Goodman DS, Zaklama MS, Gabr MK, el-Maraghy S, Patwardhan VN 1973 Serum vitamin A, retinol-binding protein, and prealbumin concentrations in protein-calorie malnutrition. I. A functional defect in hepatic retinol release. Am J Clin Nutr 26:973-981

40. Mayatepek E, Leichsenring M, Ahmed HM, Laryea MD, el-Karib AO, Bremer HJ 1991 Vitamin A supplementation in malnourished Sudanese children. Int J Vitam Nutr Res 61:268-269

41. Becker K, Savvides SN, Keese M, Schirmer RH, Karplus PA 1998 Enzyme inactivation through sulfhydryl oxidation by physiologic NO carriers. Nat Struct Biol 5:267-271

42. Wink DA, Vodovotz Y, Grisham MB, DeGraff W, Cook JC, Pacelli R, Krishna M, Mitchell JB 1999 Antioxidant effects of nitric oxide. Methods Enzymol 301:413-424

43. Burney S, Caulfield JL, Niles JC, Wishnok JS, Tannenbaum SR 1999 The chemistry of DNA damage from nitric oxide and peroxynitrite. Mutat Res 424:37-49 
44. Rudic RD, Sessa WC 1999 Nitric oxide in endothelial dysfunction and vascular remodeling: clinical correlates and experimental links. Am J Hum Genet 64:673-677

45. Grisham MB, Jourd'Heuil D, Wink DA 1999 Nitric oxide. I. Physiological chemistry of nitric oxide and its metabolites: implications in inflammation. Am J Physio 276:315-321

46. Halliwell B 1996 Oxidative stress, nutrition, and health. Experimental strategies for optimization of nutritional antioxidant intake in humans. Free Radic Res 25:57-74

47. Walker MW, Kinter MT, Roberts RJ, Spitz DR 1995 Nitric oxide-induced cytotoxicity: involvement of cellular resistance to oxidative stress and the role of glutathione in protection. Pediatr Res 37:41-49
48. Park SH, Aust AE 1998 Regulation of nitric oxide synthase induction by iron and glutathione in asbestos-treated human lung epithelial cells. Arch Biochem Biophys 360:47-52

49. Farghali H, Hynie S, Vohnikova Z, Masek K 1997 Possible dual role of nitric oxide in oxidative stress injury: a study in perfused hepatocytes. Int J Immunopharmacol 19:599-605

50. Sergent O, Griffon B, Morel I, Chevanne M, Dubos MP, Cillard P, Cillard J 1997 Effect of nitric oxide on iron-mediated oxidative stress in primary rat hepatocyte culture. Hepatology 25:122-127

51. Mayatepek E, Becker K, Gana L, Hoffmann GF, Leichsenring M 1993 Leukotrienes in the pathophysiology of kwashiorkor. Lancet 342:958-960 